\title{
ANÁLISE DOS MÉTODOS DE DIFERENÇAS FINITAS E EXPANSÃO RÁPIDA NA MIGRAÇÃO REVERSA NO TEMPO
}

\author{
Edvaldo Suzarthe de Araujo \\ Orientador: Dr. Reynam da Cruz Pestana (UFBA) \\ 109 p. - Dissertação (Mestrado) - Defesa 18.09.2009
}

\begin{abstract}
RESUMO. A migração reversa no tempo é considerada o método mais preciso de se fazer migração de dados sísmicos. Entretanto, sua principal restrição é alta demanda computacional requerida por esse método. Portanto, métodos numéricos que aceleram a extrapolação do campo de ondas são particularmente importantes. Nesta dissertação, fazemos um estudo da utilização dos métodos numéricos de diferenças finitas e expansão rápida na migração reversa no tempo. Discutimos também, as condições de estabilidade e dispersão numérica do método de diferenças finitas e fazemos uma análise das expansões de Taylor e Chebyshev para a função cosseno, uma vez que esta função aparece na solução analítica da equação da onda no domínio do tempo. Neste trabalho, demonstramos que a partir do método de expansão rápida aplicado na solução analítica da equação da onda é possível obter a solução da equação da onda que utiliza aproximações de diferenças finitas de qualquer ordem no tempo. Além disso, mostramos que a grande vantagem do método de expansão rápida é que ele permite realizar a extrapolação do campo de ondas usando um intervalo de amostragem temporal maior do que o utilizado pelo método de diferenças finitas na migração reversa no tempo. Para avaliarmos 0 desempenho dos métodos numéricos utilizamos os dados de afastamento nulo do modelo-1 SEG/EAGE, cuja frequência máxima é de $45 \mathrm{~Hz}$ e com intervalo de amostragem temporal de $8 \mathrm{~ms}$. Usando o método de diferenças finitas conseguimos imagear com boa precisão os dados reamostrados para $2 \mathrm{~ms}$ e $4 \mathrm{~ms}$. Já com o método de expansão rápida foi possível realizarmos a migração dos dados originais, com uma redução significativa no tempo de processamento. Também aplicamos esses métodos numéricos num dado simples a fim de observarmos 0 efeito da dispersão numérica e testamos com sucesso 0 método de expansão rápida na migração reversa no tempo de famílias de tiro comum.
\end{abstract}

ABSTRACT. The reverse-time migration is considered the most accurate method to perform seismic migration, but its limited by high computational requirements. So numerical methods that accelerate the extrapolation of the wave field are particularly important. In this thesis, we study the use of numerical finite difference and rapid expansion methods in the reverse-time migration. We also discuss the conditions of stability and numerical dispersion for the finite difference method and we make an analysis of the Taylor and Chebyshev expansions for the cosine function, since this function appears in the analytical solution of wave equation in the time domain. In this work, we demonstrated that the rapid expansion method applied in the analytical solution of wave equation can provide the same solution of the wave equation using finite difference approximations of any order in time. We show also that the great advantage of the rapid expansion method is that it can be used to extrapolate wave fields with a sampling interval time greater than normally used by the finite difference method in reverse time migration. To evaluate the numerical perform of these methods we used the zero-offset dataset of the SEG/EAGE model-1 which has as maximum frequency $45 \mathrm{~Hz}$ and time sampling interval $8 \mathrm{~ms}$. Using the finite difference method we image with good accuracy the dataset resampled to $2 \mathrm{~ms}$ and $4 \mathrm{~ms}$. However, with the rapid expansion method was possible to migrate the original data with a significant reduction in processing time. We also use these numerical methods in a single data in order to observe the effect of the numerical dispersion and tested with success the rapid expansion method in the reverse-time migration method of a common shot dataset. 